\title{
STUDI ANALISIS-KOMPARATIF METODE DALÂLAH AL-NASH DAN MAFHÛM MUWÂFAQAH DALAM PENGGALIAN MAKNA NASH SYAR'I
}

\author{
Abdul Jalil \\ Jurusan Syari'ah dan Ekonomi STAIN Pamekasan, \\ Jln. Panglegur KM. 04 Pamekasan.email:jllhasan683@gmail.com
}

\begin{abstract}
Abstrak:
Nash al-Qurân dan Hadîts mengandung makna dan esensi yang harus ditangkap secara tepat oleh manusia, tentunya menangkap makna dan esensi yang berada dalam nash syar'î perlu cara atau metode sehingga nash syar'î berupa kalamullah yang mengandung norma hukum dan panduan kehidupan manusia tersebut dapat diimplementasikan dalam kehidupan yang nyata. Dalam Ilmu Metodologi Istinbâth Hukum Islam, Jumhûr Mutakallimîn dalam menggali makna nash memilih dengan menggunakan metode Manthûq dan Mafhûm Muwâfaqah. Sementara golongan Fuqâha', mereka memilih berbeda dalam mencari, menggali dan menafsiri makna nash syar'î dengan metode dalâlah al-nash.
\end{abstract}

\begin{abstract}
:
Nash of al-Qur'an and Hadits contains meaning and essential that must be understood well by man. It means we need a way or method in order nash syar'i that is kalamullah containing law norm and human's life guide can be implemented in the real life. In methodology of istinbath islamic law, Jumhur Mutakallimin in looking for the meaning of nash chooses by using Manthuq and Mafhum Muwafagh method. While Fuqaha', they chooses different way in looking for, understanding and interpreting the meaning of nash syar'i by dalalah al-nash method.
\end{abstract}

\section{Kata Kunci:}

Dalâlah al-nash, Mafhûm muwâfaqah, Nash syar'i 


\section{Pendahuluan}

Perbedaan adalah sebuah keniscayaan. Itu artinya bahwa perbedaan merupakan sesuatu yang tidak mungkin dihindari. Apabila dilihat dari berbagai aspek, maka perbedaan merupakan kondisi alami (fitrah). Perbedaan berkait erat dengan perbedaan personal dalam batasan yang lebih jauh. Sangat mustahil terbentuk sebuah sistem kehidupan dan membangun sebuah sistem kehidupan serta membangun interaksi sosial diantara manusia yang sama rata dalam berbagai hal. ${ }^{1}$

Diantara sekian banyak perbedaan yang mengemuka adalah perbedaan dalam kesimpulan hukum Islam. Terutama halnya dalam masâil furû'iyah (masalah yang tidak prinsip) sebagaimana yang direkam jelas oleh khadzanah klasik keIslam-an dalam karya kepustakaan ulama'-ulama' terdahulu. Seiring dengan perkembangan zaman dengan perubahan pola hidup masyarakat dan kemajuan teknologi, perbedaanperbedaan tersebut menjadi semakin nyata. Sebab bagaimanapun, rumusan fikih para mujtahid (beserta para pengikutnya) yang dikonstruksi ratusan tahun yang lalu tentu tidak memadai untuk menjawab semua persoalan.

Apabila ditelusuri lebih jauh, perbedaan pendapat para imam mujtahid (baca: madzhab) tidak hanya berbeda dalam pendapat dan kesimpulan hukum saja. Mereka bahkan berbeda dalam manhaj atau metode dalam menggali hukum. Sebagai contoh, mujtahid-mujtahid yang tergabung dalam komunitas sunn $\hat{\imath}$ saja $^{2}$ terdapat dua aliran yang berada dalam kutub

\footnotetext{
1 Abbas Arfan, Geneologi Pluralitas Madzhab dalam hukum Islam, (Malang: UIN-Malang Pers, 2008), hlm. 1.

2 Secara garis besar madzhab terbagi menjadi tiga komunitas, yaitu Sunnî, Syi'î dan Khawârij. Dalam komunitas Sunnî terdapat 13 (tiga belas) madzhab, diantaranya empat madzhab yang masih bertahan dan berkembang (madzhab Hanafi, Mâliki, Syâfi'i dan Hambalî). Untuk komunitas Syi'î terdapat empat madzhab, tiga diantaranya masih berkembang (Ja'farî, Zaidî dan Ismâ̂ilî̀). Yang terakhir, komunitas Khawârij hanya terdapat satu madzhab yang berkembang, yakni madzhab 'Ibâdi
} 
berseberangan, yakni ahl al-ra'yi (rasionalis-logis) dan ahl alhadîts (tradisional empiris).

Pertama, Aliran ahl al-ra'yi yang berkembang di Kufah

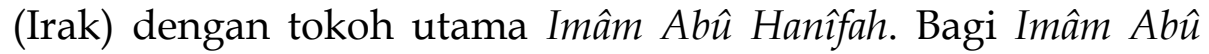
Haniffah sumber utama hukum Islam adalah al-Qur'ân, lalu alSunnah dengan melalui seleksi yang ketat, dan yang ketiga Fatwâ Sahabat. Dalam hal ijtihad digunakan Ijmâ', Qiyâs, Istihsân dan 'Urf. Kedua, Aliran ahl al-hadîts yang berkembang di Madînah (Hijâz), dengan tokoh utama Imâm Mâlik ibn Anas. Bagi Imâm Mâlik, sumber utama hukum Islam adalah al-Qur'ân, kemudian al-Sunnah dan; yang Ketiga, Tradisi ahli (penduduk) Madînah. Sementara itu dalam berijtihad, beliau menggunakan Qiyâs, Istishlâh, Istihsân, dan Sadd al-Dzarî'ah. ${ }^{3}$ Berkenaan dengan sumber yang ketiga tersebut (tradisi ahli Madînah), Imâm Mâlik

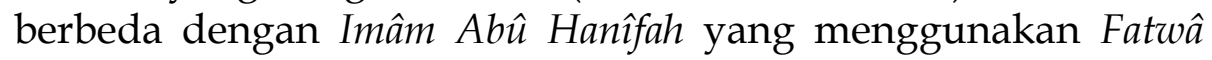
Sahabat tanpa membatasi sahabat yang tinggal di Madinah atau lainnya.

Di kalangan para pakar Ushul Fikih terjadi perbedaan pendapat dalam menilai layak tidaknya sebuah metode dalam menafsirkan, menganalisa dan menggali makna nash (teks) syar'î (al-Qur'ân dan Hadîts). Misalnya, dalam al-Qur'ân, ayatayat tertentu menegaskan arah konstan dari semua peristiwa dan tindakan Tuhan, sementara ayat-ayat lainnya mengungkapkan inisiatif, kebebasan, tanggung jawab manusia dan lainnya. Beragam kandungan makna itu diperlukan satu metode tertentu untuk menggalinya. ${ }^{4}$

Kendatipun perbedaan dalam memandang dan pemakaian metode dalam menganalisa makna nash (teks) syar'î terkadang menghasilkan kesimpulan hukum yang sama. Sebagai contoh, adanya perbedaan antara ulama' ushul fikih aliran mutakallimîn yang menggunakan mafhûm mukhâlafah

\footnotetext{
${ }^{3}$ Abbas Arfan, Geneologi Pluralitas Madzhab dalam hukum Islam, hlm. 9-10.

4 Wilfred Cantwell Smith, Kitab Suci Agama-agama (Bandung: PT. Mizan Publika, 2005), Cet. I, hlm. 79.
} 
sebagai metode penggalian makna nash syar'î, dengan ulama' ushul fikih aliran Ahnâf (pengikut Imam Abû Hanîfah) yang menganggap mafhûm mukhâlafah tidak layak menjadi metode. Mereka pun menilai bahwa nash syar'î tidak menunjuk kepada hukum yang diambil dari pemahaman yang terbalik dari nash tertulis. Sebab kesimpulan hukum sebaliknya dapat ditemukan dari dalil hukum lainnya.

Atas dasar semua ini peneliti ingin memberikan elaborasi dan pembahasan secara fokus dan mendalam. Pertama; Apa perbedaan antara metode dalâlah al-nash dan mafhûm muwâfaqah? Kedua, Manakah yang lebih unggul antara metode dalâlah al-nash dan mafhûm muwâfaqah?

\section{Metode Penelitian}

Penelitian ini merupakan penelitian kepustakaan dengan pendekatan kualitatif, sementara sumber data dalam penelitian ini adalah literatur yang representatif yang mewakili pendapat ulama' ushul fikih aliran Hanafiyah dan Mutakallimîn terutama yang membahas metode dalâlah al-nash dan mafhûm muwâfaqah. Analisis data dalam penelitian ini adalah dengan melakukan reduksi data (merangkum, memilih hal-hal yang pokok berupa data, menfokuskan pada hal-hal yang penting). Kemudian menyajikan data dalam bentuk uraian singkat dan hubungan antar teori. Barulah kemudian menarik kesimpulan dan verifikasi.

\section{Hasil Penelitian dan Pembahasan Mafhûm Muwâfaqah}

Teori yang digunakan dalam penelitian ini adalah teori dalam ushul fikih yang dikenal dengan istilah kaidah mafhûm muwâfaqah. Akan tetapai sebelum dijelaskan mengenai mafhûm muwâfaqah, di sini akan diuraikan pengertian mafhûm terlebih dahulu. 
Secara bahasa, mafhîm merupakan isim maf' $\hat{u} l$ dari fahima (فهم) yang berarti tahu, mengerti. 5 Sedangkan secara istilah, mafhûm adalah:

$$
\text { ما دل عليه اللفظ لا في محل النطق }
$$

Artinya: "Makna yang ditunjukkan lafazh, yang makna tersebut tidak berada dalam ucapan (lafazh)". Ada pula menjelaskannya dengan definisi berbeda:

$$
\text { ما وافق المسكوت عنه المنطوق في الحكمى6 }
$$

Artinya: "Makna yang tidak terucap yang (memiliki) kesesuaian dengan makna Manthûq secara hukum".

Dengan kata lain, mafhûm adalah makna tersirat, baik berupa kesimpulan hukum maupun kedudukan perbuatan menurut hukum. ${ }^{7}$

Para ulama' ushul fikih aliran mutakallimîn membagi mafhûm menjadi dua bagian yaitu mafhûm muwâfaqah dan mafhûm mukhâlafah.

1. Mafhûm Muwâfaqah.

Mafhûm muwâfaqah adalah makna mafhûm yang selaras dengan makna manthûq-nya. Kata "selaras" maksudnya adalah adanya kesamaan antara makna mafhûm dengan makna manthûq secara hukum atau posisi. Artinya bisa selaras secara hukum saja atau bisa sepadan secara posisi (perbuatan hukumnya) saja atau bisa selaras secara hukum dan posisi (perbuatan hukumnya) sekaligus.

Akan tetapi dalam mafhûm muwâfaqah ini yang paling banyak adalah kesamaan secara hukumnya, lalu secara posisi (perbuatan hukumnya). Termasuk jarang untuk selaras secara hukum dan posisi (perbuatan hukumnya) sekaligus. ${ }^{8}$

${ }^{5}$ Mahmud Yunus, Kamus Arab - Indonesia (Jakarta: PT. Hidakarya Agung, tt.), hlm. 324.

${ }^{6}$ Muhammad ibn Husain ibn Hasan al-Jîzanî, Ma'âlim Ushûl al-Fikih 'inda Ahl alSunnah wa al-Jamâ'ah (al-Maktabah al-Syâmilah, 50 GB), hlm. 450.

${ }^{7}$ Muhammad ibn Ahmad al-Mahally, Hâsyiyah al-'Allâmah al-Bannâni, hlm. 241.

8 Ibid. 
Kaidah mafhûm muwâfaqah ini terbagi menjadi dua :

a. Lahn al-Khithâb

Lahn al-khithâb adalah jika tingkat keselarasan makna mafhîm-nya sederajat atau sama dengan makna manthûqnya. ${ }^{9}$

Contoh ayat :

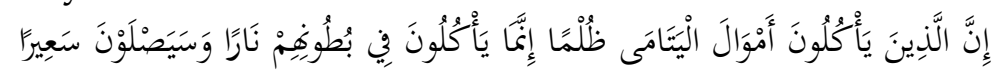

Artinya: "Sesungguhnya orang-orang yang memakan harta anak yatim secara zhâlim, sebenarnya mereka itu menelan api sepenuh perutnya dan mereka akan masuk ke dalam api yang menyala-nyala (neraka)." (QS. al-Nisa': 10)

Makna manthûq ${ }^{10}$ ayat di atas adalah larangan untuk memakan harta anak yatim secara zhâlim. Sedangkan makna mafhûm lahn al-khithâb-nya adalah larangan untuk membakar atau membinasakan harta anak yatim secara sia-sia dengan cara apapun. Larangan itu berlaku karena membakar harta anak yatim dan lainnya dinilai sama dan setara dengan makna manthîq yang dikandung ayat di atas.

Contoh lainnya adalah tentang hukum makrûh melakukan transaksi jual beli ketika dilaksanakannya ibadah shalat Jum' at yang terkandung dalam ayat:

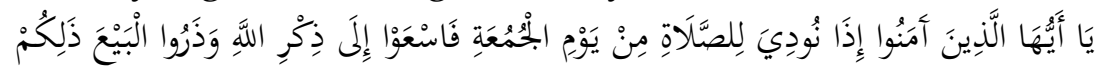

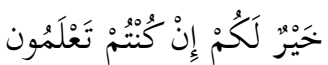

Artinya: "Hai orang-orang beriman, apabila diseru untuk menunaikan shalat Jum'at, maka bersegeralah kamu kepada mengingat Allah swt. dan tinggalkanlah jual beli. ${ }^{11}$ Yang

\footnotetext{
9 Ibid.

${ }^{10}$ Manthûq adalah makna dzâhir teks atau nash itu sendiri. Sehingga makna manthûq sering diartikan dengan makna yang dihasilkan dengan tanpa melakukan perenungan (kotemplasi).

11 Maksudnya: apabila imam telah naik mimbar dan mu'adzdzin telah adzan di hari Jum'at, maka kaum muslimin wajib bersegera memenuhi panggilan mu'adzdzin itu dan meninggalkan semua pekerjaannya.
} 
demikian itu lebih baik bagimu jika kamu mengetahui." (QS. AlJumu'ah: 9)

Ayat di atas secara manthîq mengandung makna hukum makrûh melakukan transaksi jual beli ketika sedang dilaksanakannya shalat Jum'at. Melakukan transaksi jual beli ketika sedang dilaksanakannya shalat Jum'at berposisi sebagai ashl (الأصل). Sedangkan hukum makrûh-nya adalah hukum ashl (حكم الأصل). Adapun (masalah) furû'-nya adalah melakukan akad rahn (gadai) ketika sedang dilaksanakannya shalat Jum'at.

Dari mekanisme Qiyâs di atas, ditemukan bahwa makna mafhûm lahn al-khithâb adalah makrûh-nya melakukan transaksi mu'âmalâh lainnya seperti akad rahn (gadai) dan lainnya saat ada panggilan untuk melakukan shalat Jum'at. Kesimpulan hukum makrûh akad rahn itu didapatkan melalui metode Qiyâs dengan akad jual beli ketika dikumandangkan adzan Jum'at, dengan 'illat kelalaian untuk melakukan kewajiban shalat.

Status hukum makrûh tersebut disimpulkan karena melakukan transaksi mu'âmalâh ketika Jum'at dipandang sebagai makna setara bagi transaksi jual beli yang dilaksanakan pada saat didirikannya shalat Jum'at.

b. Fahw al- Khithâb

Fahw al- khithâb adalah bila tingkat keselarasan makna mafhûm-nya lebih utama atau tinggi dari makna manthûqnya.

Contoh ayat:

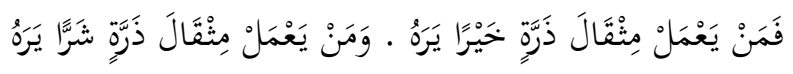

Artinya: "Barangsiapa yang mengerjakan kebaikan seberat dzarrahpun, niscaya dia akan melihat (balasan)nya. Dan barangsiapa yang mengerjakan kejahatan sebesar dzarrahpun, niscaya dia akan melihat (balasan)nya pula." (QS. Al-Zalzalah: 7-8) 
Makna manthîq ayat tersebut adalah bahwa orang yang melakukan perbuatan baik walaupun hanya seukuran biji dzarrah (sangat kecil) kelak di akhirat akan mendapat pembalasannya. Begitu juga orang yang melakukan perbuatan buruk walau hanya seukuran biji dzarrah (sangat kecil) kelak di akhirat akan mendapat pembalasannya pula. Makna mafhûm lahn al-khithâb ayat di atas adalah melakukan perbuatan sebesar biji lainnya yang seukuran dengan kecilnya biji dzarrah.

Makna mafhûm fahw al-khithâb ayat itu adalah bahwa orang yang melakukan perbuatan baik yang lebih besar dari sekedar biji dzarrah kelak di akhirat akan mendapat pembalasannya. Begitu juga orang yang melakukan perbuatan buruk yang lebih besar dari sekedar biji dzarrah kelak di akhirat akan mendapat pembalasannya pula. Sebab bila amal perbuatan sekecil biji dzarrah saja akan mendapat balasan, lebih-lebih yang lebih besar daripadanya.

Contoh ayat lainnya adalah :

$$
\text { وَلَا تَقْرَبُوا الزَّنَا إِنَُّْ كَانَ فَاحِشَة وَسَاءَ سَبِيلًا }
$$

Artinya: "Dan janganlah kamu mendekati zina; sesungguhnya zina itu adalah suatu perbuatan yang keji. Dan suatu jalan yang buruk." (QS. Al-Isra': 32)

Makna manthîq ayat di atas adalah larangan untuk melakukan perbuatan yang mendekati zina. Mafhûm lahn al-khithâb ayat di atas adalah melakukan adegan berciuman, berpelukan dengan lawan jenis yang tidak halal baginya. Pemahaman ini dicapai dengan asumsi bahwa perbuatan tersebut memiliki nilai setara dengan makna manthûq ayat itu. Sehingga muncullah makna lahn al-khithâb.

Sedangkan makna mafhûm fahw al-khithâb ayat tersebut adalah larangan melakukan zina. Secara logika bisa dicerna bahwa bila mendekatinya saja haram apalagi 
melakukan zina itu sendiri. Hal itu tentu (jauh lebih) haram. Kesimpulan makna ini didapat karena perbuatan zina dipahami sebagai pemahaman yang lebih daripada (sekedar) perbuatan pengantar zina.

Apabila ingin mengamalkan kaidah mafhûm muwâfaqah, maka diperlukan syarat sebagai berikut:

a. Harus terlebih dahulu memahami makna manthûq dalam dalil nash, seperti makna berupa penghormatan kepada kedua orang tua pada QS. al-Isra': 23. Dengan begitu kita akan mampu memahami pengharaman memukul orang tua dengan cara analogi yang lebih utama (بطريق الأولى). Karena apabila tidak memahami makna manthîq-nya, maka niscaya tidak akan memahami tentang pengharaman memukul orang tua.

b. Hendaknya mafhûm dengan analogi yang lebih utama secara hukum atau setidak-tidaknya analogi setara secara hukum. Hal ini bisa dipahami dari penunjukan makna redaksi kalimat dan sesuatu yang menunjukan dan menjelaskan keadaan (قرائن الأحوال). 12

Mengenai kehujjahannya, ulama' salaf bersepakat secara Ijmấ bahwa mafhûm muwâfaqah adalah hujjah. Bahkan Ibn Taimiyah menyatakan bahwa qiyâs aulâ juga termasuk hujjah. Sebab walaupun tidak ditunjukkan oleh khithâb ayat tersebut, namun dapat diketahui bahwa sebenarnya makna qiyâs aulâ itu lebih utama secara hukum daripada makna manthûq-nya. Sehingga mengingkari mafhûm muwâfaqah termasuk bid'ah.

2. Mafhûm Mukhâlafah

Mafhûm mukhâlafah adalah makna mafhûm yang berkebalikan dengan makna manthûq-nya. ${ }^{13}$ Sehingga dengan demikian, makna mafhûm mukhâlafah adalah makna yang berlawanan dengan makna manthûq-nya.

12 Muhammad ibn Husain ibn Hasan al-Jîzanî, Ma'âlim Ushûl al-Fikih 'inda Ahl alSunnah wa al-Jamâ'ah (al-Maktabah al-Syâmilah, 50 GB) hlm. 452.

13 Zakariyâ al-Anshâri, Ghâyah al-Wushûl, hlm. 37-38. 
Pembagian mafhîm mukhâlafah ini terbagi menjadi enam bagian :

a. Mafhûm shifah, yakni penunjukan lafazh yang diikat dengan sifat tertentu untuk meniadakan hukum dari perbuatan yang disifati, ketika tidak adanya sifat tersebut. Seperti hadits di bawah ini:

$$
\text { في سائمة الغنم زكاة }
$$

Artinya: "Pada binatang yang digembalakan ada kewajiban zakat"

Hadits ini menjelaskan bahwa hewan yang digembalakan dikenai kewajiban zakat bila mencapai ukuran nishâb. Kewajiban zakat pada hewan itu dengan catatan (qayd) bahwa ia digembalakan. Sehingga bila hewan itu tidak digembalakan, maka tidak ada kewajiban zakat. ${ }^{14}$

b. Mafhûm syarath, yaitu penunjukan lafazh yang mengandung hukum yang digantungkan kepada syarat bagi tiadanya hukum tatkala tiadanya syarat itu. Sebagaimana contoh ayat :

$$
\text { ......... }
$$

Artinya: "...Dan jika mereka (isteri-isteri yang sudah ditalak) itu sedang hamil, maka berikanlah kepada mereka nafkahnya hingga mereka bersalin..." (QS. Al-Talak: 6)

Makna manthîq ayat ini adalah wajibnya seorang mantan suami untuk menafkahi isteri yang ia talak dan sementara ia menjalani masa 'iddah dalam keadaan hamil. Adapun makna mafhûm mukhâlafah-nya adalah bahwa bila wanita yang menjalani 'iddah dalam keadaan tidak hamil, maka tidak ada kewajiban nafkah bagi si mantan suami. ${ }^{15}$

c. Mafhûm ghâyah (batas akhir), yaitu penunjukan lafazh yang mengandung hukum yang diikat dengan ghâyah dan untuk

14 Wahbah al-Zuhaily, Ushûl al-Fikih al-Islâmi (Damaskus: Dar al-Fikr, 1986), hlm. 362363.

15 Ibid. hlm. 363. 
menetapkan hukum yang berlawanan setelah ghâyah tersebut. Contoh ayat berikut :

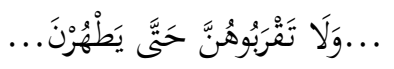

Artinya: “...dan janganlah kamu mendekati mereka, sebelum mereka suci..." (QS. al-Baqarah: 222)

Makna manthûq ayat di atas adalah larangan bagi suami untuk melakukan hubungan seksual dengan isteri yang sedang haid. Makna mafhûm mukhâlafah ayat tersebut adalah bahwa bila si isteri sudah suci maka si suami boleh menyetubuhinya.

d. Mafhûm 'adad (bilangan), adalah penunjukan lafazh yang mengandung hukum yang diikat dengan 'adad untuk menegaskan hukum dalam kasus selain yang dicakup 'adad tersebut. Seperti ayat:

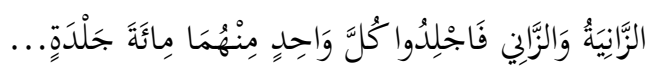

Artinya: "Perempuan yang berzina dan laki-laki yang berzina, maka deralah tiap-tiap seorang dari keduanya seratus kali dera..." (QS. Al-Nûr: 2)

Makna manthûq ayat ini adalah bahwa hukuman bagi perempuan yang berzina dan laki-laki yang berzina adalah deraan sebanyak seratus kali dera. Sedangkan makna mafhûm mukhâlafah ayat di atas adalah perempuan yang berzina dan laki-laki yang berzina tidak boleh dihukum lebih dari seratus kali dera. ${ }^{16}$

e. Mafhûm Laqab (gelar/julukan), yaitu mafhûm dari sebuah nama yang menggambarkan sebuah dzat (person) itu sendiri, baik berupa nama, sifat, nama jenis maupun macam. Seperti ayat :

$$
\text { مُحَمَّدُ رَسُولُ اللهِ... }
$$

Artinya: "Muhammad saw. itu adalah utusan Allah swt...." (QS. Al-Fath: 29)

${ }^{16}$ Ibid. hlm. 365. 
Makna manthîq ayat ini bahwa (orang yang bernama) Muhammad saw. adalah utusan Allah swt.. Sehingga mafhûm mukhâlafah-nya adalah selain Muhammad saw. bukan utusan Allah swt..

Para pakar Ushul Fikih selain al-Daqqâq sepakat bahwa mafhûm laqab bukanlah hujjah. Artinya jumhur ulama' tidak menilai mafhûm laqab sebagai hujjah karena tidak memiliki faedah dengan mengikat makna, mengkhususkan makna (takhshîsh) dan lainnya. ${ }^{17}$

f. Mafhûm Hashr (pembatasan), yakni meniadakan sesuatu yang dibatasi dari selainnya yang dihitung dan tetapnya (kesimpulan) yang berlawanan. Seperti Hadits:

$$
\text { إنما الأعمال بالنيات... (الحديث) }
$$

Artinya: "Hanya saja amal itu tergantung kepada niat..." (alHadîts)

Makna manthûq penggalan hadits di atas adalah bahwa amal perbuatan yang dinilai hanya terbatas pada amal perbuatan yang dilandasi dengan niat. Mafhûm mukhâlafahnya menunjukkan bahwa amal perbuatan yang tidak dilandasi dengan niat maka tidak akan ada penilaian.

Ada beberapa syarat yang harus dipenuhi untuk mengamalkan mafhûm mukhâlafah. Syarat tersebut secara global disebutkan bahwa qayd yang mengikat hukum tidak boleh ada kepentingan dan faedah lain kecuali untuk menghasilkan hukum ketika tidak adanya qayd. Namun secara rinci dapat dipaparkan sebagai berikut :

1. Qayd (restriksi) tidak boleh ada untuk menjelaskan sesuatu yang paling umum dan paling biasa terjadi. Dengan kata lain bahwa yang disebutkan (manthûq) bukan suatu hal yang biasanya terjadi.

\footnotetext{
17 Ibid. hlm. 365-366.
} 
2. Lafazh yang diucapkan tidak karena dalam keadaan tertekan untuk menyebutkan makna tak terucap. Seperti kalimat yang dilontarkan orang yang baru masuk Islam :

$$
\text { تصدق بهذا على المسلمين ! }
$$

Artinya: "Sedekahkanlah ini kepada orang-orang Islam!"

Sebenarnya maksud orang tersebut adalah untuk bersedekah tidak hanya kepada orang Islam tapi juga kepada orang non muslim. Tapi karena khawatir dituduh munafik, maka keterangan non muslim tersebut urung disebutkan. Pernyataan semacam ini tidak bisa diambil mafhûm mukhâlafah, seperti kesimpulan bahwa sedekah tersebut tidak boleh diberikan kepada orang non muslim. Hal itu karena si mutakallim tidak bermaksud demikian.

3. Lafazh yang diucapkan tidak untuk menjelaskan kenyataan (yang terjadi ketika lafazh itu disampaikan). Semisal kalimat:

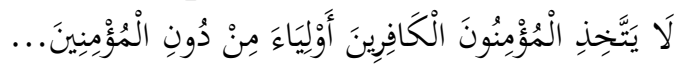

Artinya: "Janganlah orang-orang mukmin mengambil orang-orang kafir menjadi wali dengan meninggalkan orang-orang mukmin..." (QS. Ali Imran: 28)

Ayat ini menjelaskan tentang larangan untuk mengangkat orang non muslim sebagai pemimpin serta memberikan loyalitas (kesetiaan) kepada mereka yang seringkali berujung dengan mengabaikan orang-orang mukmin. Makna manthîq ini tidak bisa diambil makna secara mafhûm mukhâlafah, dengan deskripsi bahwa boleh mengangkat pemimpin dari kalangan non muslim dengan tanpa mengabaikan orang mukmin.

Sebab penyebutan "dengan meninggalkan orang-orang mukmin" sebagai penjelasan terhadap kenyataan di lapangan. Dengan kata lain, biasanya bila memberikan loyalitas kepada orang non muslim, maka akan mengabaikan orang-orang mukmin. 
4. Lafazh tersebut muncul bukan karena ada pertanyaan atau (menjelaskan) kejadian. Terlebih lagi bila si penanya tidak mengerti tentang hukum yang tidak dijelaskan (maskût). ${ }^{18}$

Mengenai kehujjahannya, terjadi silang pendapat di kalangan para ulama' dalam persoalan apakah mafhûm mukhâlafah merupakan hujjah atau bukan. Sehingga dalam masalah ini, para ulamấ terbagi dalam dua kelompok.

Kelompok pertama adalah jumhur ulama'. Mereka sepakat bahwa mafhûm mukhâlafah -selain mafhûm laqabmerupakan hujjah yang wajib diamalkan. Terutama, bila berkaitan dengan makna pada nash ketika menunjukkan pada hukum yang di-taqyîd dengan qayd. Sebab hal itu menunjuk kepada tetapnya hukum yang berlawanan ketika tiadanya qayd tersebut. ${ }^{19}$

Kelompok pertama ini menyatakan bahwa mafhûm mukhâlafah sudah diamalkan sejak dahulu oleh para sahabat dan hal ini diakui oleh Rasul saw. Pendapat ini didasarkan pada hadits:

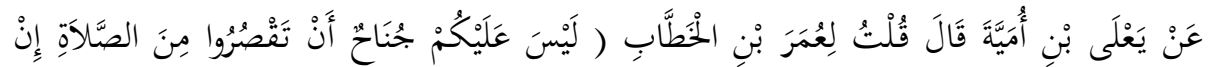

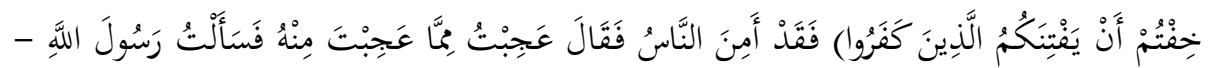

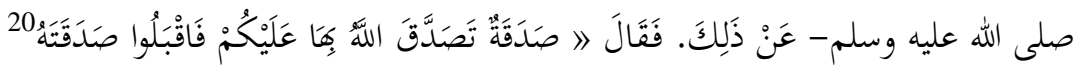

Artinya: "Dari Ya'la ibn Umayyah, ia menuturkan: aku membacakan (sebuah ayat al-Qur'ân) kepada Umar ibn Khattâb, "Dan apabila kamu bepergian di muka bumi, maka tidaklah mengapa kamu menqashar ${ }^{21}$ shalat(mu), jika kamu takut diserang orang-orang kafir."

\footnotetext{
18 Zakariyâ al-Anshâri, Ghâyah al-Wushûl, hlm. 38.

19 Wahbah al-Zuhaily, Ushûl al-Fikih al-Islâmi, hlm. 367.

20 Muslim ibn Hujjâj ibn Muslim al-Qusyairî, Shâhih Muslim (al-Maktabah alSyâmilah, 50GB), juz II, hlm. 143.

21 Menurut pendapat jumhur arti qashar di sini ialah shalat yang empat rakaat dijadikan dua rakaat. Mengqashar di sini ada kalanya dengan mengurangi jumlah rakaat dari 4 menjadi 2, yaitu di waktu bepergian dalam keadaan aman dan ada kalanya dengan meringankan rukun-rukun dari yang 2 rakaat itu, yaitu di waktu dalam perjalanan dalam keadaan khauf. Dan ada kalanya lagi meringankan rukunrukun yang 4 rakaat dalam keadaan khauf di waktu hadhar.
} 
Sekarang keadaan manusia telah aman. Lalu Umar berkata: Sungguh aku merasa heran pada apa yang kau herankan, kemudian aku menanyakan hal itu kepada Rasûl saw. Lalu Rasûl saw menjawab: (itu adalah) sedekah yang disedekahkan oleh Allah swt. dengan ayat tersebut untuk kamu sekalian. Maka terimalah sedekah pemberianNya."

Bila dikaji ayat dalam hadits di atas menunjukkan bahwa musafir boleh melakukan qashar (meringkas shalat) ketika bepergian dengan alasan khawatir akan keamanan mereka. mafhûm mukhâlafah-nya adalah bahwa bila keadaan sudah aman, maka si musafir tidak boleh melakukan qashar.

Potret yang berhasil direkam dalam hadits di atas adalah bahwa Rasûl saw tidak mengingkari perbuatan sahabat Umar yang mengambil pemahaman dari makna ayat tersebut dengan menggunakan metode mafhûm mukhâlafah. Meskipun kemudian ternyata jelas bahwa mafhûm mukhâlafah tidak perlu diamalkan dalam pemaknaan ayat ini. ${ }^{22}$

Kelompok kedua menyatakan bahwa mafhûm mukhâlafah bukanlah hujjah. Kelompok ini dimotori oleh kalangan Ahnâf (pengikut Imâm Abû Hanîfah) yang menganggap mafhûm mukhâlafah tidak layak menjadi metode. Mereka juga menilai bahwa nash syar'î tidak menunjuk kepada hukum yang diambil dari pemahaman yang terbalik dari nash tertulis. Sebab kesimpulan hukum sebaliknya dapat ditemukan dari dalil hukum lainnya.

22 Zakariyâ ibn Ghulâm Qâdir al-Bakistâni, Min Ushûl al-Fikih 'ala Manhaj Ahl al-Hadîts (al-Maktabah al-Syâmilah 50 GB), hlm. 145. 


\section{Dalâlah al-Nash ${ }^{23}$}

Secara kebahasaan, dalâlah (دلالة) adalah kata mufrad (tunggal) dengan jamak (دلالات). Adapun makna kata dalâlah secara bahasa berarti penunjukan. ${ }^{24}$ Sehingga dengan demikian arti kata dalâlah al-nash adalah keterangan makna yang terkandung dalam nash al-Qur'ân dan al-Sunnah berdasarkan penunjukan makna pada nash itu sendiri.

Adapun makna secara istilah, dalâlah al-nash memiliki pengertian:

$$
\text { المعنى الذي يفهم من روحه ومعقوله 25 (s) }
$$

Artinya: "Makna yang dipahami dari spirit (semangat) dan pengertian rasional dari nash."

Ada definisi lain mengenai dalâlah al-nash yaitu:

$$
\text { ما علم علة للحكم المنصوص عليه لغة لا اجتهادا ولا استنباطا26 }
$$

Artinya: "Makna yang diketahui bagi hukum yang telah ditegaskan oleh nash secara (pendekatan) bahasa tanpa (melakukan) ijtihad dan penggalian hukum".

Dengan demikian pengertian dalâlah al-nash adalah makna yang digali dari nash berdasarkan pemahaman terhadap semangat makna harfiyah tanpa melakukan ijtihad dan

\footnotetext{
${ }^{23}$ Memahami dalâlah pada nash al-Qur'ân dan Hadîts, merupakan suatu cara yang sangat efektif ketika melakukan istinbâth hukum. Karena, tanpa memahami dalalâh pada kedua nash ini siapa saja tidak akan mampu menjangkau atau mencapai makna apa yang sebenarnya dari suatu teks. Karenanya, dalam kajian Ushul Fikih ini, pembahasan tentang dalâlah lafazh nash merupakan salah satu yang harus diperhatikan dalam proses istinbâth hukum. Terlebih lagi, beberapa nash syari'at terkadang menunjukkan makna yang berbilangan dengan metode yang banyak pula seperti metode ibârah, metode isyârah, metode dalâlah dan metode iqtidlấ. Selain itu penunjukan makna nash tidak terbatas kepada makna yang dipahami dari makna ibârah dan bentuk-bentuknya. Sebab terkadang juga menunjukkan kepada makna yang dipahami dari metode isyârah, metode dalâlah dan metode iqtidlâ' .

${ }_{24}$ Mahmud Yunus, Kamus Arab-Indonesia, hlm. 129.

${ }^{25}$ Abd Wahhab Khallaf, Ilmu Ushûl al-Fikih (Jakarta: Dâr al-Kutub al-Islâmiyah, 2010), Cet. I, hlm. 130.

${ }^{26}$ Ahmad ibn Muhammad al-Syâsyi, Ushûl al-Syâsyi, hlm. 104.
} 
penggalian hukum. Untuk lebih jelasnya bisa dikaji seperti dalam ayat di bawah ini:

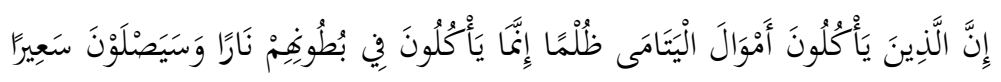

Artinya: "Sesungguhnya orang-orang yang memakan harta anak yatim secara zalim, sebenarnya mereka itu menelan api sepenuh perutnya dan mereka akan masuk ke dalam api yang menyala-nyala (neraka)." (QS. al-Nisa': 10)

Makna ibârah ayat di atas adalah larangan untuk memakan harta anak yatim secara dzâlim. Adapun makna dalâlah-nya adalah larangan untuk membakar dan merusak harta anak yatim. Kedua hal itu dilarang karena dipandang sama dengan memakannya yang berujung pada musnahnya harta anak yatim. Dengan kata lain, diharamkan segala upaya yang mengakibatkan harta anak yatim menjadi binasa, baik itu dengan memakannya, membuangnya, membakarnya atau merusaknya. ${ }^{27}$

Pemahaman ini bisa diperoleh hanya dengan melakukan upaya untuk memahami bahasa semata, tanpa harus melakukan Qiyâs atau ijtihad sekalipun. Sebab tanpa melakukan keduanya, makna dalâlah al-nash sudah dapat dicerna.

Makna dalâlah al-nash juga bisa digali dari ayat di bawah ini:

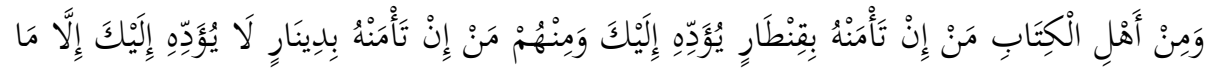

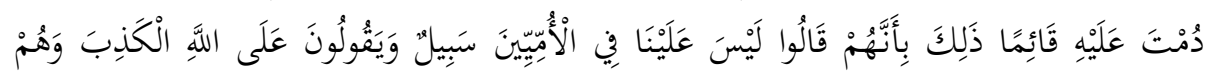

$$
\text { يَعْلَمُونَ }
$$

Artinya: "Diantara Ahli kitab ada orang yang jika kamu mempercayakan kepadanya harta yang banyak, dikembalikannya kepadamu; dan diantara mereka ada orang yang jika kamu mempercayakan kepadanya satu dinar, tidak dikembalikannya kepadamu kecuali jika kamu selalu menagihnya. Yang demikian itu lantaran mereka mengatakan: "tidak ada dosa bagi kami terhadap

${ }^{27}$ Abd. Wahhâb Khallâf, Ilmu Ushûl al-Fikih, hlm. 130. 
orang-orang ummi. Mereka berkata dusta terhadap Allah swt., padahal mereka mengetahui". (QS. ali Imran: 75)

Salah satu makna ibârah ayat di atas menegaskan bahwa sebagian ahli kitab ada yang tidak dapat dipercaya, yakni apabila dipercayakan kepada mereka satu dinar saja maka mereka tidak akan mengembalikannya kepada orang yang memercayakannya. Makna dalâlah al-nash ayat ini adalah bahwa ahli kitab semacam itu tidak bisa dipercayakan kepadanya harta yang banyak. Sebab bila dipercayakan satu dinar saja sudah enggan mengembalikan, apalagi lebih dari angka tersebut (satu dinar).

Contoh ayat lainnya:

$$
\text { فَ.... }
$$

Artinya: "...barangsiapa yang menetapkan niatnya dalam bulan itu akan mengerjakan haji, maka tidak boleh rafats, berbuat fasik dan berbantah-bantahan di dalam masa mengerjakan haji...". (QS. alBaqarah: 197)

Ayat di atas memiliki makna Ibârah tentang larangan untuk berkata 'kotor', berbuat fasik dan berbantah-bantahan ketika melakukan ibadah haji. Sebagaimana pendapat mufassir Ibn Abbas, ayat ini juga menjadi dalil yang mengharamkan melakukan hubungan seksual bagi orang yang sedang dalam keadaan Ihram. Kesimpulan itu didapat dengan pendekatan dalâlah al-nash. Sebab bila berkata kotor -yang sekiranya bisa memancing birahi- saja dilarang apalagi melakukan jima', tentu lebih dilarang. ${ }^{28}$

\section{Perbedaan Pandangan antara Jumhûr Mutakallimîn dan Ahnâf}

Perbedaan cara pakar Ushul Fikih Jumhîr Mutakallimîn dan Ahnâf tidak hanya berkutat pada perbedaan antara mafhûm muwâfaqah dan dalâlah al-nash saja. Para ulama' juga berselisih pandang dalam hal pemaknaan harfiyah yakni manthîq dan

28 Wizârah al-Auqâf wa al-Syu'ûn al-Islâmiyyah al-Kuwaitiyah, al-Mausû'ah alFikihiyyah al-Kuwaitiyyah (al-Maktabah al-Syâmilah 50GB), juz II, hlm. 513. 
ibârah al-nash dan lainnya. Perbedaan itu tidak hanya dalam pengistilahan tapi juga pendekatan dalam melakukan analisa teks syari'at.

Manthîq dalam terminologi Jumhûr Mutakallimîn ini akan dijumpai bandingannya dengan istilah ibârah al-nash menurut terminologi Ahnâf. Keduanya berbeda dalam penjelasan definisi masing-masing, walaupun secara prinsipil eksistensi keduanya bisa dinilai sama. Hanya saja secara redaksional kalangan Ahnâf melakukan pemilahan makna ibârah antara makna asal (أصالة) dan makna yang turut menyertai (تبع), sedangkan Jumhûr Mutakallimîn tidak melakukan pemilahan semacam itu. ${ }^{29}$

Seperti makna ayat :

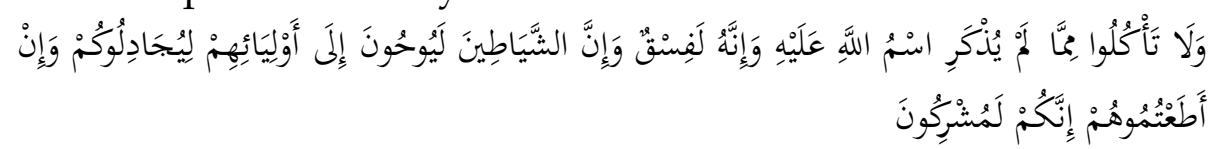

Artinya: "Dan janganlah kamu memakan binatang-binatang yang tidak disebut nama Allah swt. ketika menyembelihnya. Sesungguhnya perbuatan yang semacam itu adalah suatu kefasikan. Sesungguhnya syaitan itu membisikkan kepada kawan-kawannya agar mereka membantah kamu; dan jika kamu menuruti mereka, sesungguhnya kamu tentulah menjadi orang-orang yang musyrik." (QS. al-An'am: 121)

Ayat ini secara ibârah mengandung makna pengharaman memakan hewan yang disembelih tanpa menyebut nama Allah swt. Dalam pemaknaan dengan analisa manthûq, maka akan dijumpai makna yang tidak berbeda. Itu berarti bahwa pemahaman ibârah sebanding dengan makna manthîq menurut Jumhûr. ${ }^{30}$

\footnotetext{
${ }^{29}$ Muhammad Aqshari, al-Manthîq wa al-Mafhûm Bain Madrasatai al-Mutakallimîn wa al-Fuqahấ' (al-Maktabah al-Syamilah 50 GB), hlm. 5.

30 'Iyâdl ibn Nâmiy al-Salmî, Ushûl al-Fikih La Yasa' al-Faqîh Jahluh (al-Maktabah alSyâmilah 50 GB), hlm. 265.
} 
Untuk lebih jelasnya perhatikan tabel dibawah ini:

\begin{tabular}{|c|c|c|c|}
\hline Sampel Ayat & $\begin{array}{l}\text { Metode } \\
\text { Analisa }\end{array}$ & $\begin{array}{c}\text { Makna yang } \\
\text { ditangkap }\end{array}$ & $\begin{array}{c}\text { Pemilahan } \\
\text { Makna }\end{array}$ \\
\hline \multirow[t]{2}{*}{ 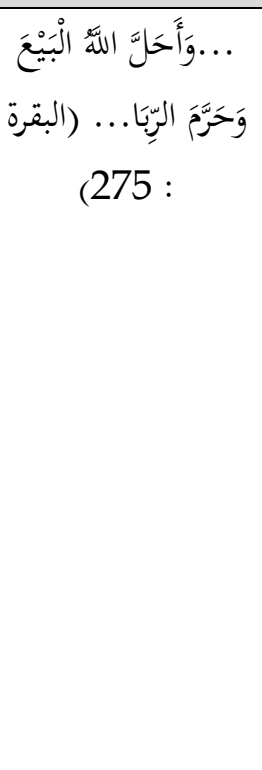 } & $\begin{array}{l}\text { Ibârah al- } \\
\text { nash }\end{array}$ & $\begin{array}{l}\text { - Pertama, jual } \\
\text { beli tidak sama } \\
\text { dengan ribâ; } \\
\text { - Kedua, } \\
\text { hukum jual beli } \\
\text { halal dan ribâ } \\
\text { haram. }\end{array}$ & $\begin{array}{l}\text { - Makna pertama } \\
\text { adalah makna } \\
\text { asal (أصالة) } \\
\text { - Makna kedua } \\
\text { adalah makna } \\
\text { yang turut } \\
\text { menyertai (تبعا) }\end{array}$ \\
\hline & Manthûq & $\begin{array}{l}\text { - Pertama, jual } \\
\text { beli tidak sama } \\
\text { dengan ribâ; } \\
\text { - Kedua, } \\
\text { hukum jual beli } \\
\text { halal dan ribâ } \\
\text { haram. }\end{array}$ & Tidak ada \\
\hline
\end{tabular}

\section{Penggalian Makna Nash dengan Mafhûm Muwâfaqah}

\section{Mafhûm Muwâfaqah sebagai Metode Qiyâs}

Selain dianggap sebagai metode analisa lafazh (فظية), mafhûm muwâfaqah juga dinilai sebagai metode qiyâsiyah (قياسية). Pendapat ini disuarakan oleh Imâm Syafi'î, Imâm Haramain dan Imâm al-Râzi. ${ }^{31}$ Bahkan mereka menyebutkan secara tegas bahwa selain nash al-Qur'ân dan Hadîts lalu dijumpai pemahaman yang semakna dengan keduanya, maka hal itu disebut Qiyâs. ${ }^{32}$

Bila mafhûm muwâfaqah dianggap sebagai bagian dari bentuk Qiyâs, itu tidak lain karena mafhûm muwâfaqah menilai sama perbuatan yang diatur oleh nash dengan perbuatan yang

\footnotetext{
${ }^{31}$ Muhammad ibn Ahmad al-Mahallî, Hâsyiyah al-'Allâmah al-Bannâni, juz I, hlm. 243.

32 Muhammad ibn Husain ibn Hasan al-Jîzani, Ma'âlim Ushûl al-Fikih 'inda Ahl alSunnah wa al-Jamâ'ah (al-Maktabah al-Syâmilah 50 GB), hlm. 451.
} 
tidak diatur oleh nash dengan berdasarkan kesamaan 'illat (alasan) yang menjadi dasar hukum (wâjib, harâm, makrûh, sunnah, dan mubâh) suatu perbuatan hukum.

Hanya saja ada perbedaan antara mafhûm muwâfaqah sebagai metode analisa lafazh dan metode Qiyâs, bila mafhûm muwâfaqah sebagai metode analisa lafazh dicukupkan dengan melakukan eksplorasi dan eksploitasi makna pada nash secara kata perkata, maka untuk mafhûm muwâfaqah sebagai metode Qiyâs lebih rumit. Itu tidak lain karena dalam prosesnya harus melalui mekanisme Qiyâs. Misalnya dengan menentukan ashl, far', hukm al-ashl dan 'illat.

Dari mekanisme itu mafhûm muwâfaqah sebagai metode Qiyâs akan menentukan makna standar (qiyâs musâwwi) dan makna di atas standar (qiyâs aulawî). Makna standar (qiyâs musâwi) adalah makna setara dibanding ashl dan hukm al-ashl. Sedangkan makna di atas standar (qiyâs aulawî) merupakan makna yang lebih parah nilai maknanya dibanding ashl dan hukm al-ashl-nya.

Lebih jelasnya perhatikan contoh berikut:

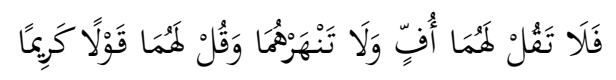

Artinya: "Maka sekali-kali janganlah kamu mengatakan kepada keduanya perkataan "ah" dan janganlah kamu membentak mereka dan ucapkanlah kepada mereka perkataan yang mulia". (QS. al-Isra': 23)

Kandungan manthîq ayat ini adalah larangan secara tegas berkata " $a h$ " kepada kedua orang tua. Makna inti pada teks ayat ini adalah larangan melakukan perbuatan yang sekiranya bisa

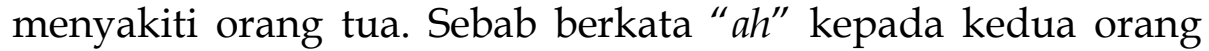
tua secara kausalitas akan berujung pada perasaan tersakiti bagi keduanya. Pemahaman ini diperoleh dari analisa lafazh sekaligus jaringan makna yang dihubungkan dengan makna nilai kata serta kausalitasnya.

Dengan pertimbangan analisa lafazh itu kemudian ditemukan pula makna serupa. Makna serupa ini tingkat keharamannya sama (lahn al-khithâb), yakni larangan mencaci, 
mengolok, dan mengintimidasi kedua orang tua. Sebab semua itu memiliki nilai sama (setara) dengan berkata " $a h$ " kepada kedua orang tua, yaitu menyakiti.

Selain itu dijumpai pula makna serupa dengan tingkat keharamannya yang lebih parah, yakni memukul dan menendang kedua orang tua. Pemahaman akan "keharaman yang lebih parah ini" berdasarkan nilai makna dari kata memukul yang secara kausalitas jauh menyakitkan daripada sekedar berkata " $a$ ".

Bahkan bila dilakukan dengan serius, perbuatan memukul bisa menyebabkan seseorang kehilangan nyawa. Sedangkan berkata " $a h$ " sekalipun mempunyai nilai makna menyakiti tidak sampai beresiko terbunuhnya seseorang. Karenanya, perbuatan memukul orang tua tingkat keharamannya lebih parah ketimbang berkata " $a h$ " kepada keduanya. Makna semacam inilah yang disebut dengan fahw alkhithâb. ini:

Lebih simpelnya bisa diperhatikan pada tabel di bawah

\begin{tabular}{|c|c|c|c|}
\hline \multirow[b]{2}{*}{$\begin{array}{l}\text { Makna } \\
\text { Manthûq }\end{array}$} & \multirow[b]{2}{*}{ Mekanisme Qiyas } & \multicolumn{2}{|c|}{ Makna Mafhûm Muwâfaqah } \\
\hline & & $\begin{array}{c}\text { Qiyâs } \\
\text { Musâwwî̀ }\end{array}$ & $\begin{array}{c}\text { Qiyâs } \\
\text { Aulawî̀ }\end{array}$ \\
\hline $\begin{array}{l}\text { Larangan } \\
\text { berkata } \\
\text { "ah" } \\
\text { kepada } \\
\text { kedua } \\
\text { orang tua }\end{array}$ & $\begin{array}{l}\text {-Ashl (الأصل) : Berkata “Ah" } \\
\text { kepada kedua orang tua } \\
\text {-Hukm al-ashl (الأصل): (الفرع): Memukul kedua } \\
\text { Haram } \\
\text { - Far' } \\
\text { orang tua } \\
\text { - 'illat (العلة): Menyakiti (الفليذاء) }\end{array}$ & $\begin{array}{l}\text { Larangan } \\
\text { mencaci dan } \\
\text { menghina } \\
\text { kedua orang } \\
\text { tua }\end{array}$ & $\begin{array}{l}\text { Larangan } \\
\text { memukul } \\
\text { kedua } \\
\text { orang tua }\end{array}$ \\
\hline
\end{tabular}

Contoh lainnya adalah tentang hukum makrûh melakukan transaksi jual beli ketika dilaksanakannya ibadah shalat Jum'at yang terkandung dalam ayat: 


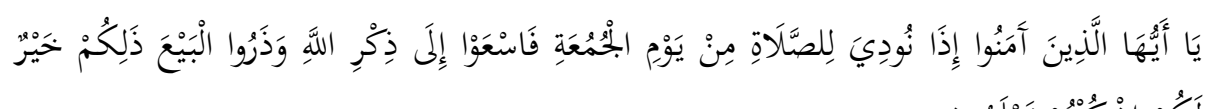

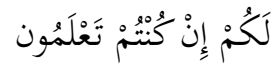

Artinya: "Hai orang-orang beriman, apabila diseru untuk menunaikan shalat Jum'at, maka bersegeralah kamu kepada mengingat Allah swt. dan tinggalkanlah jual beli. Yang demikian itu lebih baik bagimu jika kamu mengetahui." (QS. al-Jumu'ah: 9)

Ayat di atas secara manthîq mengandung makna hukum makrûh melakukan transaksi jual beli ketika sedang dilaksanakannya shalat Jum'at. Melakukan transaksi jual beli ketika sedang dilaksanakannya shalat Jum'at berposisi sebagai ashl (الأصل). Sedangkan hukum makrûh-nya adalah Hukm al-ashl (حكم الأصل). Adapun (masalah) far'-nya adalah melakukan akad rahn (gadai) ketika sedang dilaksanakannya shalat Jum'at.

Dari mekanisme Qiyâs di atas, ditemukan bahwa makna mafhûm lahn al-khithâb adalah makrûh-nya melakukan transaksi mu'âmalah lainnya seperti akad rahn (gadai) dan lainnya saat ada panggilan untuk melakukan shalat Jum'at. Kesimpulan hukum makruh akad rahn itu didapat setelah dilakukan Qiyâs dengan akad jual beli ketika dikumandangkan adzan Jum'at, dengan 'illat kelalaian untuk melakukan kewajiban shalat. Status hukum makrûh tersebut disimpulkan karena melakukan transaksi mu'âmalah ketika Jum'at dipandang sebagai makna setara bagi transaksi jual beli yang dilaksanakan pada saat didirikannya shalat Jum'at.

Lebih detailnya penjelasan kandungan surat al-Jumu'ah: 9, perhatikan tabel di bawah ini: 


\begin{tabular}{|c|c|c|c|}
\hline \multirow{2}{*}{$\begin{array}{l}\text { Makna } \\
\text { Manthûq }\end{array}$} & \multirow{2}{*}{ Mekanisme Qiyas } & \multicolumn{2}{|c|}{$\begin{array}{c}\text { Makna Mafhûm } \\
\text { Muwâfaqah }\end{array}$} \\
\hline & & $\begin{array}{c}\text { Qiyâas } \\
\text { Musâwwî̀ }\end{array}$ & $\begin{array}{c}\text { Qiyâs } \\
\text { Aulawî̀ }\end{array}$ \\
\hline $\begin{array}{l}\text { Larangan } \\
\text { melakukan } \\
\text { transaksi } \\
\text { jual beli } \\
\text { ketika } \\
\text { dilaksanaka } \\
\text { nnya shalat } \\
\text { Jum'at }\end{array}$ & $\begin{array}{l}\text {-Ashl (الأصل) : Melakukan } \\
\text { transaksi jual beli ketika } \\
\text { dilaksanakannya shalat Jum'at } \\
\text {-Hukm al-ashl (الفرل): (الفرع): Melakukan transaksi } \\
\text { - Farûh } \\
\text { rahn (gadai) ketika } \\
\text { dilaksanakannya shalat Jum'at } \\
\text { - 'illat (العغله عن الصلاة): kelalaian terhadap } \\
\text { kewajiban melakukan shalat }\end{array}$ & $\begin{array}{l}\text { Larangan: } \\
\text { Melakukan } \\
\text { transaksi } \\
\text { jual beli } \\
\text { ketika } \\
\text { dilaksanaka } \\
\text { n-nya shalat } \\
\text { Jum'at }\end{array}$ & \\
\hline
\end{tabular}

\section{Mafhûm Muwâfaqah sebagai Metode Analisa Lafazh}

Dalam upaya melakukan eksplorasi makna teks syari'at, para ulama' masih memperdebatkan apakah mafhûm muwâfaqah merupakan analisa lafazh (لفظية) atau lebih kepada qiyâsiyah (قياسية). Dalam sebuah pendapat para ulama' berpendapat bahwa mafhûm muwâfaqah adalah metode analisa lafazh. Pemaknaan ini diupayakan dengan melakukan eksploitasi segala yang memungkinan makna permakna yang dikandung lafazh nash.

Pendapat ini diutarakan oleh al-Ghazâlî dan al-Amudî. Mereka menegaskan bahwa penunjukan lafazh dapat ditemukan dengan menggunakan mafhûm muwafâqah dengan melakukan analisa lafazh dan tidak ada sangkut pautnya dengan Qiyâs. Makna nash dimaksud bisa dipahami dengan berdasar pada 
redaksi nash dan beberapa penanda (qarinah) tidak hanya dari lafazh semata. 33

Seperti halnya pada contoh ayat:

$$
\text { وَلَا تَقْرَبُوا الزَّنَا إِنَّهُ كَانَ فَاحِشَةَ وَسَاءَ سَبِياًَ }
$$

Artinya: "Dan janganlah kamu mendekati zina; sesungguhnya zina itu adalah suatu perbuatan yang keji. Dan suatu jalan yang buruk." (QS. al-Isra': 32)

Makna manthûq ayat di atas adalah larangan untuk melakukan perbuatan yang mendekati zina. Mendekati zina bisa dipahami dengan perbuatan berpegangan tangan dengan lain jenis yang tidak halal, adegan berciuman (kissing) dan lainnya. Ini pemahaman yang setara dengan tingkat makna standar atau lahn al-khithâb. Bila mendekati zina dilarang, maka begitu pula dengan perbuatan berpegangan tangan, berciuman dan lainnya.

Sedangkan makna di atas standar atau mafhûm fahw alkhithâb ayat tersebut adalah larangan melakukan zina. Secara logika bisa dicerna bahwa bila mendekatinya saja haram apalagi melakukan zina itu sendiri. Hal itu tentu makna melambung di atas standar. Sehingga bila mendekati zina dihukumi haram, maka begitu pula jika melakukan zina maka pasti (jauh lebih) haram.

Penunjukan makna nash semacam ini bersifat majâz, yakni dengan menyebutkan perkara yang paling khusus di atas perkara umum. Perkara umumnya adalah keharaman melakukan zina sedangkan perkara khususnya adalah larangan melakukan perbuatan yang mendekati zina. Pengungkapan semacam ini sangat efisien dan efektif karena akan mencakup dua makna sekaligus.

Sederhananya, andai kata nash di atas menuntut manusia untuk tidak melakukan zina saja, maka niscaya keharaman melakukan perbuatan zina tidak akan bisa dipahami. Hal itu karena dalam sebagian kasus disebutkan bahwa seseorang

${ }^{33}$ Muhammad ibn Ahmad al-Mahally, Hâsyiyah al-'Allâmah al-Bannâni, Juz I, hlm. 244. 
berkata kepada yang lain “jangan kau lakukan perbuatan yang mendekati zina, tapi lakukan zina tersebut!"

Pemahaman tersebut sebagaimana dalam analisa makna mafhûm pada ayat tentang keharaman berkata " $a h^{\prime \prime}$ pada surat al-Isrâ': 23. ${ }^{34}$ Redaksi nash pada ayat tersebut bisa mencakup dua hal sekaligus, yakni kewajiban menghormati orang tua dan keharaman berkata " $a h$ " kepada keduanya.

Andai kata nash tersebut disampaikan dengan redaksi kewajiban menghormati orang tua saja, maka niscaya keharaman berkata " $a h$ " tidak dapat dipahami dari nash tersebut. Karena dalam kasus tertentu kadang orang berkata kepada orang lain: "jangan kau caci si Fulan, tapi pukullah dia!"

Lebih jelasnya bisa diperhatikan pada tabel di bawah ini:

\begin{tabular}{|c|c|c|c|}
\hline \multirow[b]{2}{*}{$\begin{array}{l}\text { Sampel } \\
\text { ayat yang } \\
\text { dikaji }\end{array}$} & \multirow[b]{2}{*}{$\begin{array}{l}\text { Makna } \\
\text { Manthûq }\end{array}$} & \multicolumn{2}{|c|}{ Makna Mafhûm Muwâffaqah } \\
\hline & & Lahn al-Khithâb & $\begin{array}{c}\text { Fahw al- } \\
\text { Khithâb }\end{array}$ \\
\hline 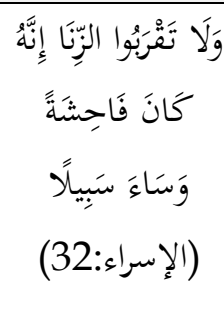 & $\begin{array}{l}\text { Larangan } \\
\text { melakukan } \\
\text { perbuatan } \\
\text { yang } \\
\text { mendekati } \\
\text { zina }\end{array}$ & $\begin{array}{l}\text { Larangan } \\
\text { bergandengan } \\
\text { tangan dan } \\
\text { berciuman dengan } \\
\text { lain jenis yang } \\
\text { tidak halal dan }\end{array}$ & $\begin{array}{l}\text { Larangan } \\
\text { melakukan } \\
\text { zina }\end{array}$ \\
\hline
\end{tabular}

Penggalian Makna Nash dengan Dalâlah al-Nash

\section{Dalâlah al-Nash sebagai Metode Qiyâs}

Di sisi lain, dalâlah al-nash dianggap sebagai metode sebagaimana teknik pemaknaan Qiyâs. Pendapat ini disuarakan oleh mujtahid Imâm Syafi'î, Imâm Rafi'î, dan lainnya. Pendapat ini didukung dan dinilai shahih oleh Abûu Ishâq bahkan al-Qaffal al-Syasyî secara jelas memasukkan dalâlah al-nash dalam macammacam Qiyâs. Namun al-Shairafî berpendapat lebih detail

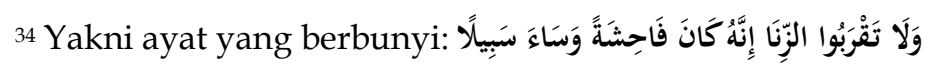


dengan menilai bahwa dalâlah al-nash adalah qiyâs jâlîy. Pendapat ini didukung oleh Sulaim. ${ }^{35}$

Bila dalâlah al-nash dipandang sebagai Qiyâs maka dapat dideskripsikan sebagai berikut. Secara teori dasar dalâlah al-nash, ayat di bawah ini mengandung makna tentang larangan mengucap “ah" (التأفيف) kepada kedua orang tua:

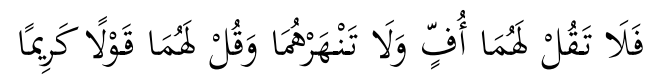

Artinya: "Maka sekali-kali janganlah kamu mengatakan kepada keduanya perkataan "ah" dan janganlah kamu membentak mereka dan ucapkanlah kepada mereka perkataan yang mulia". (QS. al-Isra': 23)

Menurut teori dasar dalâlah al-nash ayat tersebut juga mencakup keharaman memukul kedua orang tua. Sebab semangat atau spirit dan makna rasional ayat ini adalah larangan melakukan perbuatan yang menyakiti kepada kedua orang tua. Secara rasional dapat dipahami bahwa, bila berkata " $a h^{\prime \prime}$ saja menyakiti apalagi memukul, tentu perbuatan itu lebih menyakiti. Sehingga jika status hukum mengucap " $a h$ " kedua orang tua adalah haram, maka begitu juga dengan status hukum memukul kedua orang (yakni haram pula).

Bila kemudian teori dalâlah al-nash dinilai sebagai Qiyâs maka akan timbul makna dan kesimpulan hukum yang tidak berbeda dengan sentuhan sistematika yang berbeda. Hal itu disesuaikan dengan mekasnisme penggalian hukum yang diatur dalam teori Qiyâs yang meliputi empat komponen inti yakni ashl, hukm al-ashl, far' dan 'illat. Dengan keempat komponen inti tersebut akan ditemukan hukum far' yang sebelumnya menjadi misteri karena tidak dicover dan tidak diatur oleh nash.

35 Muhammad al-Zarkasyi, al-Bahr al-Muhîth (al-Maktabah al-Syamilah 50 GB), juz 4, hlm. 418 . 
Pandangan ini dapat dijelaskan dengan sampel keharaman memukul kedua orang tua yang di-Qiyâs-kan dengan keharaman mengucap " $a h$ " kepada kedua orang tua. Lebih jelasnya akan diurai oleh deskripsi tabel di bawah ini :

\begin{tabular}{|c|c|c|}
\hline $\begin{array}{l}\text { Makna } \\
\text { Ibârah }\end{array}$ & Mekanisme Qiyas & $\begin{array}{c}\text { Makna Dalâlah al- } \\
\text { Nash }\end{array}$ \\
\hline $\begin{array}{l}\text { Larangan } \\
\text { berkata " } a h \text { " } \\
\text { kepada } \\
\text { kedua orang } \\
\text { tua }\end{array}$ & $\begin{array}{l}\text {-Ashl (الأصل) : Berkata “ah” } \\
\text { kepada kedua orang tua } \\
\text {-Hukm al-ashl (الفرع): Memukul kedua } \\
\text { Haram } \\
\text { - Far' (العلة)): } \\
\text { orang tua } \\
\text { - 'illat (العلة): Menyakiti (الإيذاء) }\end{array}$ & $\begin{array}{l}\text { - Larangan mencaci dan } \\
\text { menghina kedua orang } \\
\text { tua } \\
\text { - Larangan memukul } \\
\text { kedua } \\
\text { orang tua }\end{array}$ \\
\hline
\end{tabular}

\section{Dalâlah al-Nash sebagai Metode Analisa Lafazh}

Eksistensi dalâlah al-nash sebagai salah satu metode penggalian makna nash syari'at dipandang sebagai metode dengan dualisme teknik pemaknaan. Pada satu sisi dalâlah alnash dinilai sebagai metode dengan teknik pemaknaan analisa lafazh. Analisa ini tentu meliputi penelusuran makna serta nilainya yang dicakup oleh lafazh. Seperti halnya dalam memahami ayat berikut ini:

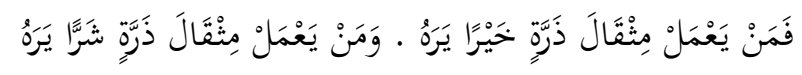

Artinya: "Barangsiapa yang mengerjakan kebaikan seberat dzarrahpun, niscaya dia akan melihat (balasan)nya. Dan barangsiapa yang mengerjakan kejahatan sebesar dzarrahpun, niscaya dia akan melihat (balasan) nya pula." (QS. al-Zalzalah: 7-8)

Makna ibârah ayat tersebut adalah bahwa perbuatan baik walau hanya seukuran biji dzarrah (sangat kecil) kelak di akhirat akan mendapat pembalasannya. Begitu juga orang yang melakukan perbuatan buruk walau hanya seukuran biji dzarrah (sangat kecil) kelak di akhirat akan mendapat pembalasannya 
pula. Makna dalâlah ayat ini adalah bahwa bila kemudian amal perbuatan sekecil biji dzarrah saja akan dibalas, terlebih lagi bila amal perbuatan yang lebih besar darinya juga akan dibalas oleh Allah swt. di akhirat kelak.

Kesimpulan ini didapat dari analisa lafazh dan maknanya yang berkaitan erat dengan logika bahasa. Sebagai contoh, bila seseorang mampu melihat benda kecil, sudah barang tentu bisa melihat benda dalam bentuk yang besar. Sebab, melihat benda kecil lebih sulit daripada melihat benda berukuran besar. Bila yang kecil saja bisa dilihat, maka yang mudah pun sudah pasti mampu dilihat.

Pemahaman ini cukup bisa dipetik dari pemahaman terhadap bahasa. Itu berarti bahwa pemahaman ini bisa dicapai tanpa harus bersusah payah dengan melakukan ijtihad dan pengamatan secara serius dan mendalam (النظر). Hanya saja diperlukan pengembangan dalam melakukan pemaknaan.

\begin{tabular}{|c|c|c|}
\hline Sampel ayat & Makna Ibârah & Makna Dalâlah al-Nash \\
\hline 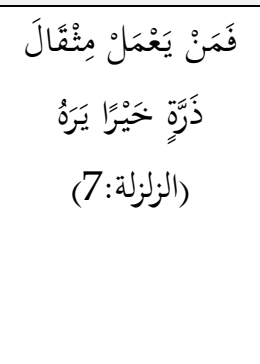 & $\begin{array}{l}\text { perbuatan baik } \\
\text { walau hanya } \\
\text { seukuran biji dzarrah } \\
\text { (sangat kecil) kelak } \\
\text { di akhirat akan } \\
\text { mendapat } \\
\text { pembalasannya }\end{array}$ & $\begin{array}{l}\text { Amal perbuatan yang } \\
\text { lebih besar dari biji } \\
\text { dzarrah akan dibalas oleh } \\
\text { Allah swt. di akhirat }\end{array}$ \\
\hline
\end{tabular}

Kelebihan dan Kekurangan Mafhûm Muwâfaqah dengan Dalâlah al-Nash

Sebelum melakukan penilaian mafhûm muwâfaqah dan dalâlah al-nash sangat penting melakukan perbandingan keduanya dalam melakukan analisa makna nash syari'at. Pertama-tama akan dideskripsikan keduanya dengan pendekatan mekanisme Qiyâs. Sebagai contoh ketika kedua 
metode tersebut mencoba untuk mengeksplorasi makna salah satu penggalan nash al-Qur'an yaitu pada surat al-Isrâ': 23. Ayat ini mengandung tentang larangan berkata " $a h$ " kepada kedua orang tua.

Perbandingan dimaksud bisa dianalisa perbedaannya secara lebih gamblang pada tabel di bawah ini:

\begin{tabular}{|c|c|c|c|}
\hline \multirow{2}{*}{$\begin{array}{c}\text { Makna } \\
\text { Manthûq }\end{array}$} & \multirow{2}{*}{ Mekanisme Qiyas } & \multicolumn{2}{|c|}{ Makna Mafhûm Muwâfaqah } \\
\hline & & Qiyâs Musâwwî & Qiyâs Aulawî \\
\hline $\begin{array}{l}\text { Larangan } \\
\text { berkata } \\
\text { "ah" } \\
\text { kepada } \\
\text { kedua } \\
\text { orang } \\
\text { tua }\end{array}$ & 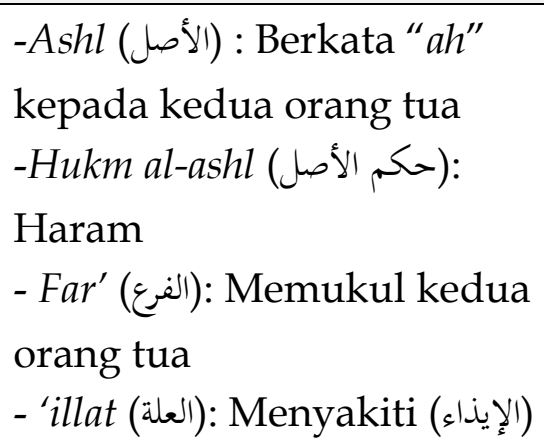 & $\begin{array}{l}\text { Larangan } \\
\text { mencaci dan } \\
\text { menghina } \\
\text { kedua orang } \\
\text { tua }\end{array}$ & $\begin{array}{l}\text { Larangan } \\
\text { memukul } \\
\text { kedua orang } \\
\text { tua }\end{array}$ \\
\hline
\end{tabular}

Analisa surat al-Isrâ': 23 dengan menggunakan mafhûm muwâfaqah dengan pendekatan Qiyâs.

\begin{tabular}{|c|c|c|}
\hline $\begin{array}{l}\text { Makna } \\
\text { Ibârah }\end{array}$ & Mekanisme Qiyas & Makna Dalâlah al-Nash \\
\hline $\begin{array}{l}\text { Larangan } \\
\text { berkata } \\
\text { “ah" kepada } \\
\text { kedua } \\
\text { orang tua }\end{array}$ & $\begin{array}{l}\text {-Ashl (الأصل) : Berkata } \\
\text { “Ah” kepada kedua } \\
\text { orang tua } \\
\text {-Hukm al-ashl ( الأصل): Haram } \\
\text { - Far' (الفرع): Memukul } \\
\text { kedua orang tua } \\
\text { - 'illat (العلة): Menyakiti } \\
\text { (الإيذاء) }\end{array}$ & $\begin{array}{l}\text { - Larangan mencaci dan } \\
\text { menghina kedua orang tua } \\
\text { - Larangan memukul kedua } \\
\text { orang } \\
\text { Tua }\end{array}$ \\
\hline
\end{tabular}

Analisa surat al-Isrâ': 23 dengan menggunakan

Dalâlah al-Nash dengan pendekatan Qiyâs 
Dari dua tabel di atas dapat dilihat bahwa tidak dapat dipungkiri bahwa ada kesamaan antara mafhûm muwâfaqah dan dalâlah al-nash. Hal itu terbukti dengan kesamaan makna yang dihasilkan oleh keduanya. Kesimpulan ini merupakan hasil perbandingan kedua metode dari satu sisi, yakni sisi kesamaan.

Di sisi lain ditemukan perbedaan antara mafhûm muwâfaqah dan dalâlah al-nash. Perbedaan keduanya terletak pada makna setelah melalui mekanisme Qiyâs. Secara makna normatif keduanya tampak tidak ada perbedaan, tetapi pada pemilahan maknanya sangat berbeda.

Untuk mafhûm muwâfaqah ada pemilahan antara makna qiyâs musâwwi dan qiyâs aulawî. Qiyâs musâwwî adalah makna setara dengan makna manthûq dan qiyâs aulawî merupakan makna lebih utama dibanding makna Manthûq. Sedangkan untuk dalâlah al-nash tidak ada pemilahan makna sebagaimana mafhûm muwâfaqah. Dalâlah al-nash menyimpulkan makna-makna yang sesuai dengan semangat dan rasio nash tanpa menilai apakah makna tersebut setara dengan makna ibârah ataukah lebih utama ketimbang makna ibârah.

Perbandingan antara mafhûm muwâfaqah dan dalâlah alnash bisa juga bisa dikaji dengan pendekatan analisa lafazh (لفظية). Sebagai contoh analisa dalâlah al-nash dan mafhûm muwâfaqah ketika membedah makna al-Isrâ': 32 .

Lebih jelasnya bisa disimak pada dua tabel di bawah ini:

\begin{tabular}{|c|c|c|}
\hline Sampel ayat & $\begin{array}{l}\text { Makna } \\
\text { Ibârah }\end{array}$ & Makna Dalâlah al-Nash \\
\hline 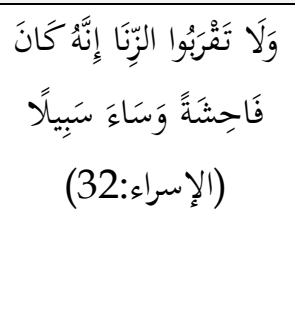 & $\begin{array}{l}\text { Larangan } \\
\text { melakukan } \\
\text { perbuatan } \\
\text { yang } \\
\text { mendekati } \\
\text { zina }\end{array}$ & $\begin{array}{l}\text {-Larangan bergandengan } \\
\text { tangan dan berciuman } \\
\text { dengan lain jenis yang tidak } \\
\text { halal dan } \\
\text {-Larangan melakukan zina }\end{array}$ \\
\hline
\end{tabular}

Analisa surat al-Isrâ': 32 dengan menggunakan dalâlah al-nash dengan pendekatan analisa lafazh 


\begin{tabular}{|c|c|c|c|}
\hline \multirow[b]{2}{*}{ Sampel ayat } & \multirow[b]{2}{*}{$\begin{array}{c}\text { Makna } \\
\text { Manthûq }\end{array}$} & \multicolumn{2}{|c|}{ Makna Mafhûm Muwâffaqah } \\
\hline & & $\begin{array}{c}\text { Lahn al- } \\
\text { Khithâb } \\
\text { (makna setara) }\end{array}$ & $\begin{array}{c}\text { Fahw al- } \\
\text { Khithâb } \\
\text { (makna lebih } \\
\text { tinggi) }\end{array}$ \\
\hline كَالَا تَقْرَبُوا الزَّنًَا إِنَّهُ & $\begin{array}{l}\text { Larangan } \\
\text { melakukan } \\
\text { perbuatan } \\
\text { yang } \\
\text { mendekati } \\
\text { zina }\end{array}$ & $\begin{array}{l}\text { Larangan } \\
\text { bergandengan } \\
\text { tangan dan } \\
\text { berciuman } \\
\text { dengan lain } \\
\text { jenis yang tidak } \\
\text { halal dan }\end{array}$ & $\begin{array}{l}\text { Larangan } \\
\text { melakukan } \\
\text { zina }\end{array}$ \\
\hline
\end{tabular}

Analisa surat al-Isrâ': 32 dengan menggunakan mafhîm muwâfaqah dengan pendekatan analisa lafazh

Dari kedua tabel di atas dapat ditarik kesimpulan bahwa dengan pendekatan analisa lafazh ada perbedaan antara mafhûm muwâfaqah dan dalâlah al-nash. Perbedaannya terletak pada pemilahan makna setara dan makna lebih utama. Dalam mafhûm muwâfaqah ada pemilahan antara makna setara dengan kategori lahn al-khithâb dan makna lebih utama dengan kategori fahw al- khithâb.

Pemilahan semacam ini tidak dijumpai dalam dalâlah alnash. Lagi-lagi dalâlah al-nash hanya menyimpulkan maknamakna yang sesuai dengan semangat dan rasio nash tanpa menilai apakah makna tersebut setara dengan makna ibârah ataukah lebih utama ketimbang makna ibârah.

\section{Penutup}

Dari pembahasan dan analisa serta elaborasi dari berbagai nash al-Qurân yang sudah penulis tanpilkan dapat ditarik kesimpulan dari fokus kajian dalam penelitian ini bahwa: Pertama, Perbedaan antara metode dalâlah al-nash dan mafhûm muwâfaqah dalam mengungkap makna nash syar'î adalah adanya pemilahan makna setara (lahn al-khithâb/qiyâs 
musâwî) dan makna lebih utama (fahw al-khithâb/qiyâs aulawi) dalam mafhûm muwâfaqah. Sementara, dalam metode dalâlah alnash tidak ada pemilahan sebagaimana yang terdapat dalam metode mafhûm muwâfaqah. Kedua, Metode mafhûm muwâfaqah lebih unggul daripada metode dalâlah al-nash, hal ini dapat dibuktikan dengan adanya pemilahan makna (lahn al-khithâb/qiyâs musâwi) dan (fahw al-khithâb/qiyâs aulawi).

\section{Daftar Pustaka}

Alî, Ahmad bin Muhammad bin Ishâq al-Syâsyî Abû. Ushûl alSyâsyî. al-Maktabah al-Syâmilah, 50GB.

Anshâri al-, Abu Zakariya. Ghâyah al-Wushûl. Surabaya: alHidâyah, tt.

Aqshari, Muhammad. al-Manthîq wa al-Mafhûm bain Madrasati al-Mutakallimîn wa al-Fuqahâ'. al-Maktabah alSyamilah, 50GB.

Arfan, Abbas. Geneologi Pluralitas Madzhab dalam Hukum Islam. Malang: UIN-Malang Pers, 2008.

Bakistâni al-, Zakariyâ ibn Ghulâm Qâdir. Min Ushûl al-Fikih 'ala Manhaj Ahl al-Hadîts. al-Maktabah al-Syâmilah, 50GB.

Departemen Agama RI. al-Qur'ân dan Terjemahnya. Bandung: alJumanatul Ali Art, 2005.

Hasan, M. Afif. Madzhab Pelangi. Malang: Penerbit Universitas Negeri Malang, 2011.

Jîzanî al-, Muhammad ibn Husain ibn Hasan. Ma'âlim Ushûl alFikih 'inda Ahl al-Sunnah wa al-Jamấ'ah. al-Maktabah alSyâmilah, 50GB.

Khallaf, Abd Wahhab. Ilmu Ushul al-Fikih. Jakarta: Dâr al-Kutub al- Islâmiyah, 2010.

Mahallî al-, Muhammad ibn Ahmad. Hâsyiyah al-'Allâmah alBannâni. Beirut: Dar al-Fikr, 2000.

Moleong, Lexy J. Metodologi Penelitian Kualitatif. Bandung: PT. Remaja Rosdakarya, 2004. 
Mundir, dan Sukidin. Metode Penelitian Membimbing dan Mengantar Kesuksesan Anda dalam Dunia Penelitian. Surabaya: Insan Cendekia, 2005.

Qusyairi al-, Muslim ibn Hujjâj ibn Muslim. Shâhih Muslim. alMaktabah al-Syâmilah, 50GB.

Salmi al-, 'Iyâdl ibn Nâmiy. Ushûl al-Fikih La Yasa' al-Faqîh Jahluh. al-Maktabah al-Syâmilah, 50GB.

Sugiyono. Metode Penelitian Kuantitatif, Kualitatif dan RED. Bandung: Alfabeta, 2009.

Syahûd al-, 'Ali ibn Nâyif. al-Khulâshah Asbâb al-Ikhtilâf alFuqahâ'. al-Maktabah al-Syâmilah, 50GB.

Taftadzani al-. Syarh al-Talwih 'ala al-Taudlih. al-Maktabah alSyamilah, 50GB.

Wizârah al-Auqâf wa al-Syu'ûn al-Islâmiyyah al-Kuwaitiyyah. al-Mausû'ah al-Fikihiyyah al-Kuwaitiyyah. al-Maktabah al-Syâmilah, 50 GB.

Yunus, Mahmud. Kamus Arab - Indonesia. Jakarta: PT. Hidakarya Agung, tt.

Zarkasyi al-, Muhammad. al-Bahr al-Muhith. al-Maktabah alSyamilah, 50GB.

Zuhaily al-, Wahbah. Ushûl al-Fikih al-Islâmi. Damaskus: Dar alFikr, 1986. 